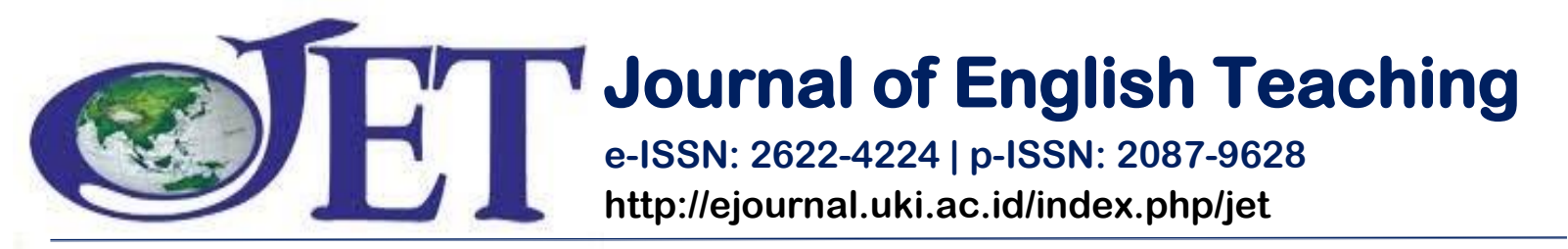

\title{
Testing Breadth and Depth of Vocabulary Knowledge and Their Relationship with Vocabulary Size of EFL Students
}

\section{Ismi Narulita Firda}

ismi_firda19@mhs.uinjkt.ac.id

Universitas Islam Negeri Syarif Hidayatullah

\section{Intan Azkiyah}

intan_azkiyah19@mhs.uinjkt.ac.id

Universitas Islam Negeri Syarif Hidayatullah

\author{
Albiansyah \\ albiaansyah@gmail.com \\ Universitas Islam Negeri Syarif Hidayatullah
}

\begin{abstract}
Testing the breadth and depth of vocabulary knowledge is needed to see its effect on the vocabulary size of EFL students. The study aims to know at the relationship between the breadth and depth of vocabulary knowledge and the vocabulary size of EFL students. This research was conducted in the $8^{\text {th }}$ grade of Trimulia Junior High School Jakarta. This research uses a correlational research design. The sample was 51 EFL learners. The Vocabulary Level Test (VLT) and the Words Associates Test (WAT) were administered in this study. The scores were presented with descriptive statistics for two tests of the breadth and depth of vocabulary knowledge. The results showed that the breadth and depth of the vocabulary knowledge test had a negative correlation with the L2 vocabulary size of EFL students. Using Statistic Product moment, the correlation coefficients found at 0.01 for the breadth and 0.11 for depth is included in the very weak category. So, there is a very weak correlation between the tests of breadth and deep vocabulary knowledge and the size of students' vocabulary.
\end{abstract}

Keywords:

breadth, depth, vocabulary knowledge, vocabulary sizes

How to cite:

Firda, I.N., Azkiyah, I. \& Albiansyah. (2021). Testing Breadth and Depth of Vocabulary Knowledge and Their Relationship with Vocabulary Size of EFL Students. Journal of English Teaching, 7(1), 89-100. DOI: https://doi.org/10.33541/jet.v7i1.2434 


\section{INTRODUCTION}

Mostly, knowing students' learning outcomes is the main goal that educators implement at the final of learning activities. The test is a need to assess learning outcomes. According to Nunan (2015), the subject that has been taught to students will determine what will be assessed. Measuring the ability of students' language requires several criteria; one of the criteria is validity, reliability, objectivity, and economy (Foyewa, 2015). The present research issue focuses on language tests. The language test is usually done by testing vocabulary knowledge and grammar. McNamara (in Roever \& McNamara, 2006) said that tests of language take a big part in the lives of substantial people, taking a part as a gateway during vital transition times in occupation, education, and transferring to other country. For teachers, the purpose of the test is clear because they need to find out about the improvement of their students (Hughes, 1989).

Specifically, students must be tested several times in one semester. The mechanism of the test depends on each school's management or even the teacher of each subject. However, the usual method of assessment is through written tests or oral tests which are the main standards for the final grade. Heaton (Heaton, 1990) divides teachers' reasons for testing into several categories; Finding of progress, Encouraging students, Finding out about learning difficulties, Finding out about achievement, Placing students, Selecting students, and Finding out about skills.

Reliability and validity are all principles that need to be considered when designing and evaluating language tests, including vocabulary. However, vocabulary testing is easier than other testing, for instance, grammar knowledge. The reason is twofold: first, it is not too difficult to identify what type of word it is; second, the units tested are more clearly separated (Nation, 2013).

Vocabulary is a core component of language proficiency and provides many bases for how well students speak, listen, read, and write. Meanwhile, according to (Cameron, 2001), vocabulary is not only about learning words but is actually more than that. It's also about studying chunks and finding words in them.

Vocabulary has importance part like language skill in the entire of language area, the significance in assessing vocabulary is the same as evaluating other skills. This is in line with Schmitt opinion (Meyer \& Schmitt, 2002). The opinion said that vocabulary is the important basic block of language. Therefore, it is reasonable in order to evaluate students' insight about vocabulary. Regarding to master a second language, vocabulary becomes an inseparable and fundamental part.

In the study of Nation (2013), students must hold over 5,000-word stock in order to be able in listening and speaking. Likewise, for language learners to start read a real text, the size of vocabulary around 3,000 words is considered as a start, and the next size of 5,000 vocabulary can be sufficient to read well (Schmitt et al., 2001). Another bigger size of vocabulary is more than 8,000-9,000-word families are needed to read English texts that are not adjusted (Nation, 2006). To provide around $80 \%$ coverage of most texts that help EFL beginner students understand communication in native language situations, they must have at least 2,000-3,000 words.

Learners also experience two dimensions in language learning such as learners only get the definition of words (vocabulary breadth) and know how far vocabularies are known as learners know the content of vocabulary depth. For instance, collocations, synonyms, and so on.

In this research, the question under discussion arises: how is the students' vocabulary knowledge and how much vocabulary can students recognize at the eighth Firda, Azkiyah \& Albiansyah (2021). Testing Breadth and Depth of Vocabulary Knowledge and ... 
grade of Trimulia Middle School? Is there the relationship between the breadth of vocabulary knowledge of EFL students' vocabulary size? Is there the relationship between the depth of vocabulary knowledge of EFL students' vocabulary size? Nevertheless, it is not easy to answer some of the questions above in this research. Hence, the core focus of present research is the vocabulary size of L2 learners in order to see how learners' vocabulary size from the knowledge of vocabulary breadth and depth testing and analyze the correlation to the knowledge of vocabulary breadth and depth.

\section{LITERATURE REVIEW}

A test is an assessment tool prepared for administrative procedures that occur at a time that can be identified in the curriculum when students master all their abilities and know that their responses are measured and assessed. In line with Kadir (2015), the effort to measure how far learning objectives have been achieved, can be done by evaluating, the case is evaluating learning outcomes. Measuring tools for evaluating learning outcomes are used tests. Tests are ways (which can be used) or procedures (which need to be pursued) in the context of measurement and assessment in the field of education.

According to Read (1993), assessing a language is related to the plan of the test to evaluate learners for any type in the aim of practical that can be compendium in any tag, such as, achievement, and proficiency. Berka (Pavlü, 2009) adds two kinds of tests, there are standardized and non-standardized tests. Tests with standardized refers to tests prepared by a professional while non-standardized tests refer to tests made by teachers based on the experience or results that they found in class. Standardized tests are also seen as highly reliable tests while non-standardized tests are the opposite. In order to design tests, the teacher or test designer is required to respect a number of principles, such as content validity, validity, reliability, the criteria related validity, construct and face validity, and practicality.

Schmitt (Meyer \& Schmitt, 2002) sees that reliability deals are related to the consistency and stability of 'a test behavior' at different times. In other words, the test can be relied upon if the test participant's scores do not change over time. The problem here, however, relates to norm-referenced testing, which is the fair assessment of testers; especially in writing test assessments since they might involve some level of subjectivity by comparing students' essays with each other for example (Kardina et al., 2013). However, the notion of validity points to the quality of the assessment with respect to measuring what should be measured (Meyer \& Schmitt, 2002). Thus, Heaton in Kardina (Kardina et al., 2013) states that a test must measure whatever is supposed to be measured and not the other; this can be interpreted, the speaking test must test only speaking rather than grammatical, which is a problem often faced with test validity.

According to Alduais (2016) there are three parts of testing language components: Testing sound system, Testing grammatical structures, and Testing vocabulary. Vocabulary indicates as a series of syllable that individual can utilize in any form such as written and oral. Vocabulary has a crucial part to reveal the concept of using the skills of receptive and productive. Such as, listening and reading as receptive. Harmer (1991) stated that if the structures of language construct the skeleton in language, so vocabularies are seen as the flesh and the pivotal organs. Like Harmer mentioned in the previous, it is interpreted that vocabulary really takes a significant place in the proficiency of language.

In addition, Read (2007) gives support to the statement, Read mention that vocabulary size assessment for L2 learners has the core of a narrower word range than 
size for natives, because low word frequencies are much less likely to be recognized, particularly by L2 students.

\section{Language Component}

Language is a daily communication tool. In understanding language, the communication tool has several components. Language is divided into components or levels. The language component is the element of language or part of the whole language. Every language has many words, and each of these words can refer to whatever it is desired.

In language acquisition, there are main components that focus in language (language components), namely acquisition of phonology, acquisition of lexicon, acquisition syntax, semantic acquisition, and pragmatic acquisition (Dardjowidjojo, 2016). Rukmana (Rukmana, 2016) adds vocabulary as an important component in language. Without vocabulary, language activities are impossible to be true. So that vocabulary mastery is very important as a support in the process of speaking.

According to Alduais (Alduais, 2016) there are three parts of testing language components: Testing sound system, testing grammatical structures, and Testing vocabulary. Vocabulary is a set of words that people can use in any form such as written and oral. Vocabulary has a crucial role to express the idea of using receptive (listening and reading) and productive (speaking and writing) skills. Harmer (Harmer, 1991) stated that if language structures construct the skeleton of language, then the vocabulary is seen as the vital organs and the flesh. As Harmer mentioned before, it can be interpreted that vocabulary has a very significant position in language proficiency.

Vocabulary has as much importance as language skills in the whole language system, the importance of assessing vocabulary is the same as evaluating other skills. This is in line with Schmitt (Schmitt, 2000), vocabulary is an important basic block of language and, therefore, it makes sense to be able to measure students' knowledge about it. With regard to mastering a second language, vocabulary is an inseparable and fundamental part. Both teachers and students spend a lot of time and energy on vocabulary acquisition. For this reason, because of the importance of vocabulary in the whole language system, it is very important to test the students' vocabulary knowledge.

\section{Testing Breadth and Depth Vocabulary knowledge}

Vocabulary knowledge depends not only on how many words a person knows, but also depends on one's ability to understand its meaning of the word. Nation (2001) states that vocabulary knowledge fields are formed, meaning, and use. In vocabulary knowledge, there are two aspects, namely the breadth and depth of vocabulary knowledge. Anderson and Freebody (1981) first made discrimination between the two dimensions of breadth vocabulary knowledge and depth vocabulary knowledge. The breadth of vocabulary knowledge refers to the full range of knowledge of a subject. The breadth of vocabulary knowledge is how much vocabulary is owned by someone who covers the basic knowledge that the person either orally or in writing. Breadth vocabulary has several vocabulary levels such as 2000 words family level, 3000 word family level, 5,000 word family level, and 10,000 word family level.

Depth of vocabulary knowledge refers to the extent to which specific topics are focused, strengthened, and explored. How well one knows lexical items refers to the depth of knowledge of one's vocabulary (Qian, 2002). Depth vocabulary knowledge refers to how much people understanding the meaning of components such as morphological awareness, semantic relationship awareness, and syntactic awareness (Proctor et.al, Firda, Azkiyah \& Albiansyah (2021). Testing Breadth and Depth of Vocabulary Knowledge and ... 
2012). In addition, Qian (1999) states that pronunciation, spelling, meaning, registers, frequency and morphological, syntactic, and collocation properties are the dimensions of the depth vocabulary knowledge component. Different approaches are made to conceptualize and measure the depth of vocabulary knowledge. Having vocabulary depth has also been linked to understanding the various meanings of words and how those meanings can be used in various contexts (Beck et al., 2002).

In conclusion, the breadth of vocabulary knowledge refers to the full range of knowledge of a subject. Meanwhile, depth of vocabulary knowledge refers to the extent to which specific topics are focused, strengthened, and explored. The depth of vocabulary knowledge can be seen from the meaning of components such as pronunciation, spelling, meaning, registers, frequency, morphological awareness, semantic relationship awareness, and syntactic awareness. Although breadth and depth are described differently, they are closely related to each other. Both have important roles in vocabulary knowledge to achieve English proficiency. As Meara (1996) said, students are more proficient in various language skills with a large vocabulary than students with a small vocabulary. Accordingly, Laufer (1998) states that vocabulary development includes two important aspects: knowing basic meanings and deepening known words which means not only consisting of vocabulary size but also increasing from shallow to deep level.

In recent years, several researchers $s$ have shown that vocabulary knowledge depends not only on how many words a person knows, but also depends on one's ability to understand the meaning of the word. According to Beck et al. (2002), vocabulary knowledge has several different levels of hearing one or two words in order to define and use them appropriately based on context. Students have two important aspects in their lexicon known as the breadth and depth of vocabulary knowledge.

When hearing vocabulary knowledge, most people will be prompted of how many words a person knows of that refers to the breadth of vocabulary (Shen, 2009). Nation (2013) states that form, meaning, and use are vocabulary knowledge fields. In distinguishing aspects, vocabulary breadth shows linear and unidimensional aspects while vocabulary depth refers to word meanings, semantic, collocations, and syntactic patterning (Bardakci, 2016). Furthermore, vocabulary breadth has coverage on oral and written forms knowledge, basic uses of the words, and their superficial meanings.

The 2000 word level

1. Original

2. Private

3. Royal Complete

4. Slow First

5. Sorry Not Public

6. Total

Figure 1. An example from the VLT

For testing vocabulary breadth knowledge, the researchers $\mathrm{s}$ use the VLT (Vocabulary Levels Test) that was originally developed by Nation (1990). The researchers use this test for two reasons: to present resistant of validity and to provide better reliability test items. Their revision of VLT proves that 30 items per level are more 
reliable than 18 items in the Native Level Test. The test achieved a reliability of 0.92 (Qian \& Schedl, 2004). This version consists of four parts representing four broad levels of vocabulary, that is, the 2000-words family level, 3000-words family level, 5000-words family levels, and 10000-words family level. Figure 1 illustrates an example is taken from the 2000 words level:

Having said that, vocabulary depth shows different characteristics. The depth of vocabulary knowledge is related to how deeply someone understands each word. Proctor et al. (2012) mentioned that vocabulary depth includes components such as morphological awareness, semantic relationship awareness, and syntactic awareness.

Furthermore, there are some tests used to extent the depth of receptive English vocabulary knowledge. One of these tests, initially named the Word Association Test (WAT), was developed by Read (2000) obtained reliability of 0.93 for the test. WAT allows researchers s not to test merely the meaning of words, like VLT, but also their use. This test contains 30 items that are intended to be assessed vocabulary depth which has two components: paradigmatic (meaning) and syntagmatic (collocation) associates. Examinees are asked to classify 4 words related to the objective word or words stimulus adjectives as shown in the excerpt below:

\begin{tabular}{|ll|ll|}
\multicolumn{4}{c}{ Natural } \\
\hline $\begin{array}{l}\text { Expected } \\
\text { real }\end{array}$ & $\begin{array}{l}\text { helpful } \\
\text { short }\end{array}$ & $\begin{array}{l}\text { foods } \\
\text { parents }\end{array}$ & $\begin{array}{l}\text { neighbors } \\
\text { songs }\end{array}$ \\
\hline
\end{tabular}

The first box contains of one synonym (or part of the meaning) of the stimulus adjective (real), while the second box contains of three nouns (food, parents, neighbors). Examinees can pick 4 accurate partners by applying one of three situations: they can pick two partners from the left box and two partners from the right box (2-2); they can pick three partners from the left box and one partner from the right box (3-1); or they can pick one association from the left box and three associates from the right box (1-3) as shown in the excerpt above. This is completed to create predicting more difficult. In printing WAT, one point is given for each accurate answer.

Various researchers have also examined the effect of vocabulary size and depth of vocabulary on reading in the EFL context. Şen \& Kuleli (2015) reported that there was a very strong significant relationship between vocabulary size and vocabulary depth as determined by a significance value of .000 , given $p<.05$. From this outcome, it will be safe to determine that there was a positive correlation between vocabulary size and vocabulary depth. Research by Şen \& Kuleli (2015) has examined the effect of vocabulary size and vocabulary depth of 361 students studying in Duzce University Foreign Language School preparation program in the spring semester of the 2013-2014 academic year. The researchers gave a series of the effect on vocabulary size and vocabulary depth tests. In contrast, in this research the breadth of vocabulary shows the preferred predictor of vocabulary size than the depth of vocabulary. Given the research from Şen \& Kuleli (2015), researchers have decided to Test Breadth and Depth of Vocabulary Knowledge and their Relationship with Vocabulary Size of EFL Students.

It is clear that the size and profile of vocabulary is more than just a quantitative aspect of the L2 dictionary. They must be considered with other parameters if sound judgment must be made (Bardakci, 2016). 


\section{METHOD}

The researchers adjusted a quantitative method and used a correlational study. Correlation can be interpreted as a study to test the relationship. Correlation is one of the statistical analysis techniques to discover the propensity of two or more variables or two data sets that vary consistently (Creswell, 2008). This research will collect data by conducting tests. In this research, tests were conducted to measure VLT (Vocabulary Levels Test) and WAT (Word Association Test). To measure the students' VLT and WAT, researchers gave them 2 online tests that consist of 30 items in Google form for 30 minutes.

The second variable is the vocabulary size, to measure the words know by students at different levels of vocabulary frequency the researchers $s$ use the formula by Nation (1990):

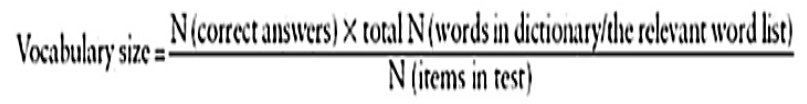

As the formula above, to find the estimated vocabulary of students by calculating the correct answer times the total word level (in this research the researchers determine the 2000 level) then divided the items in the test. From this test, we can know the estimates how much vocabulary size students can know.

The participants were 51 EFL learners at a private school in Jakarta. Their ages ranged between 13 and 16. At the first step of the testing their English proficiency levels were tested through the breadth of vocabulary knowledge. The participants were asked to do the multiple-choice test of the breadth and depth of vocabulary knowledge. The participants were not allowed to use any references or dictionaries. After that, the learners took part in the VLT (Vocabulary Level Test) and WAT (Word Association Test). To investigate their vocabulary levels, the 2000 levels of the VLT test have been selected. The researchers choose the 2000 levels of VLT because to gain understanding, foreign language learners must have at least 2000-3000 words to provide around $80 \%$ coverage of most texts. Thus, a total of 51 students multiple choice test results were processed in the vocabulary size database.

After the data of breadth and depth vocabulary knowledge and vocabulary size test data are collected. The scores of the two variables will be analyzed to determine whether or not there is a correlation between the two variables discussed in this research. In this research, the technique used is analysis with product moment statistics and testing the correlation data. Analysis with the product-moment statistical technique will be used to determine the relationship between variables while the data correlation technique test will be used to determine the level or strength of the relationship between variables. Then, add the partial correlation coefficient between the independent variable and the dependent variable by controlling other independent variables. The last is to summarize the correlation of each independent variable with the dependent variable.

\section{FINDINGS}

\section{Students' vocabulary knowledge and Mean Estimated Vocabulary Size}

Table 1 presents descriptive statistics for two tests of the breadth and depth of vocabulary knowledge: 
Table 1: Descriptive Statistic for Breath and Breath Vocabulary Knowledge Test

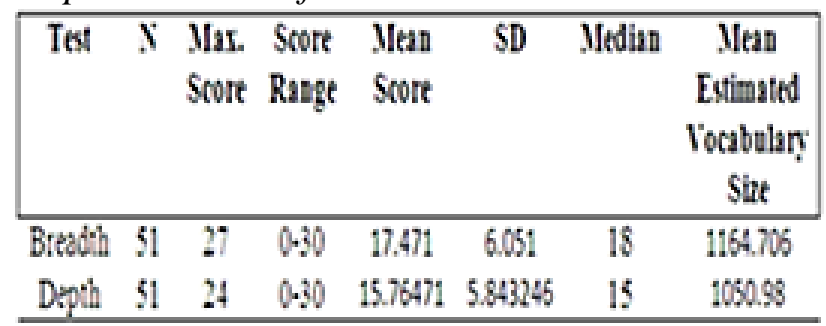

From the above data, it can be seen that the mean estimated size of the vocabulary is higher than depth.

\section{Correlation Data Analysis}

In analyzing the data, it is intended to test the analysis with a statistic product moment and test the correlation data. Table 2 shows the correlation numbers with the product moment correlation formula (rxy).

Table 2: Product moment correlation results (rxy)

\begin{tabular}{|l|l|}
\hline & Product moment correlation results $(r x y)$ \\
\hline Breadth & 0.01 \\
\hline Depth & 0.11 \\
\hline
\end{tabular}

Based on the data above, the rxy of breadth is 0.01 . While the rxy of depth is 0.11 . These calculations show a negative correlation. And if interpreted in accordance with the criteria stated above, the writer can draw a common thread that breadth and depth vocabulary knowledge tests have a correlation to the students' vocabulary size. But the correlation is very low.

The interpretation can also be done in a simple way, using guidelines such as the following:

Table 3: Guidelines for Interpretation of Product Moment Correlation Coefficients

\begin{tabular}{|c|c|}
\hline $\begin{array}{c}\text { Coefficient } \\
\text { interval }\end{array}$ & $\begin{array}{c}\text { Relationship } \\
\text { level }\end{array}$ \\
\hline $0,00-0,199$ & Very Weak \\
\hline $0,20-0,399$ & Weak \\
\hline $0,40-0,599$ & Medium \\
\hline $0,60-0,799$ & Strong \\
\hline $0,80-1,000$ & Very Strong \\
\hline
\end{tabular}

Based on the table, the correlation coefficient found at 0.01 for breadth and 0.11 for depth is incorporated in the very weak category. So, there is a very weak correlation between breadth and depth vocabulary knowledge test and students' vocabulary size. This relationship is only effective for 51 samples.

Firda, Azkiyah \& Albiansyah (2021). Testing Breadth and Depth of Vocabulary Knowledge and ... 


\section{DISCUSSION}

The relation in the vocabulary knowledge for depth and breadth may also be related to the circumstance that the reality of the word knowledge in vocabulary depth and breadth is rarely or even can never be separated. The research findings indicate that the Mean Estimated Vocabulary Size of breadth knowledge has become a stronger predictor than the depth for students' vocabulary size. This research has similar results with Wang (2014). His study did not get a positive correlation on the high breadth group, but Wang's study had a correlation on other variables. Wang's finding has negative relations on the high breadth sample with the vocabulary knowledge of depth. From the results of Wang's research, there is a tendency for some EFL learners not to develop in the vocabulary knowledge of depth with the enhancement in the breadth word knowledge. The issue is identical to this research, the main cause of negative correlation is that they use English as a foreign language. What's more, most EFL learners in learning English only have a goal to do exams and take reading exercises.

This is also in line with this research, the correlation coefficient found at 0.01 for breadth and 0.11 for depth is included in the very weak category. So, there is a very weak relationship between two kind of vocabulary knowledge test and student vocabulary size. This research is notably because factors such as students' knowledge of vocabulary, their problem in comprehending the basic information, and their condition during the testing process because these tests are conducted when the students are online learning from home, and they don't feel the test atmosphere like in class.

\section{CONCLUSION}

The statistical analysis above shows that both the breadth and depth of EFL student's vocabulary knowledge have a correlation with vocabulary size. The breadth of vocabulary knowledge of EFL students is better than the depth of vocabulary knowledge as an indicator of Mean Estimated Vocabulary Size. In general, the breadth and depth of students' vocabulary knowledge are negatively correlated with the size of their vocabulary.

From the findings, we can conclude that early and middle students must also increase the depth of their vocabulary knowledge in addition to expanding the breadth of their vocabulary knowledge. But due to time constraints and the limitations of test instruments, this research may not be comprehensive enough in terms of breadth and depth of vocabulary knowledge and vocabulary size. Therefore, the results of this research require further research support in this field.

\section{REFERENCES}

Alduais, A. M. S. (2016). Language testing: An introductory course to design tests to language components and skills with exercises, assignments, and a final test. August. King Saudi University, Lambert Academic Publishing.

Anderson, R. C. and P. Freebody. (1981). Vocabulary knowledge in J. T. Guthrie (ed.): Comprehension and Teaching: Research Reviews. International Reading Association pp. 77-117.

Bardakci, M. (2016). Breadth and Depth of Vocabulary Knowledge and Their Effects on L2 Vocabulary Profiles. English Language Teaching, 9(4), 239. https://doi.org/10.5539/elt.v9n4p239

Beck, I. L., Mckeown, M. G., \& Kucan, L. (2002). Bringing words to life. New York, The Guilford Press.

Firda, Azkiyah \& Albiansyah (2021). Testing Breadth and Depth of Vocabulary Knowledge and ...

DOI: https://doi.org/10.33541/jet.v7i1.2434 
Beck, I. L., M. G. McKeown, and L. Kucan. (2002). Bringing Words to Life: Robust Vocabulary Instruction. Guilford Press.

Cameron, L. (2001). Teaching Language to Young Learner. Cambridge: Cambridge University Press.

Creswell, J. W. (2008). Research Question and Hypotheses from Sage. Research design: Qualitative, quantitative, and mixed methods approaches, 129-144. Yogyakarta: Pustaka Pelajar.

Dardjowidjojo, Soenjono. (2005). Psikolinguistik: Pengantar pemahaman bahasa manusia. Jakarta: Yayasan Obor Indonesia.

Foyewa, D. R. (2015). Testing and Evaluation in English Language Teaching-a Case of O Level English in Nigeria. International Journal of English Language Teaching, 3(6), 32-40.

Harmer, J. (1991). The practice of English language teaching. New York: Longman. (p. 386).

Heaton, J.B. (1990). Classroom Teaching. New York: Longman.

Hughes, Arthur. (1989). Testing for language teachers. Glasgow: Cambridge University Press.

Kadir, A. (2015). Menyusun Dan Menganalisis Tes Hasil Belajar Abdul Kadir. Al-Ta'dib, $8(2), 70-81$.

Kardina, D., Natalia, M., \& Widianti, A. S. (2013). Assessment Techniques Used in the English Classes Based on Curriculum 2013 : A Suggestion. 20, 1-56.

Laufer, B. (1998). The Development of Passive and Active Vocabulary in a Second Language: Same or Different? Applied Linguistics 19(2): 255-271.

Meara, P. (1996). 'The dimensions of lexical competence' in G. Brown, K. Malmkjaer and J. Williams (eds): Performance and Competence in Second Language Acquisition. Cambridge University Press.

Meyer, L. L., \& Schmitt, N. (2002). Vocabulary in Language Teaching. TESOL Quarterly, 36(2), 235. https://doi.org/10.2307/3588334

Monolingual and Spanish-English Bilingual Children in Elementary School. Reading and Writing: An Interdisciplinary Journal, 25(7), 1635-1664.

Nation, I. S. P. (1990). Teaching and Learning Vocabulary (Vol. 13, Issue 3). Newbury House.

Nation, I. S. P. (2001). Learning vocabulary in another language. New York: Cambridge University Press.

Nation, I. S. P. (2006). How large a vocabulary is needed for reading and listening? Canadian Modern Language Review, 63(1), 59-82. https://doi.org/10.3138/cmlr.63.1.59

Nation, I. S. P. (2013). Learning Vocabulary in Another Language. In ELT Journal (2nd Editio, Vol. 56, Issue (1). Cambridge University Press. https://doi.org/10.1093/elt/56.1.91

Nunan, D. (2015). Teaching English to speakers. In Teaching english to speakers of other languages. New York: Routledge..

Pavlů, I. (2009). Testing Vocabulary. In Masaryk University Brno. Masaryk University Brno.

Proctor, C. P., Silverman, R. D., Harring, J. R., \& Montecillo, C. (2012). The role of vocabulary depth in predicting reading comprehension among English monolingual and Spanish-English bilingual children in elementary school. Reading and Writing, 25(7), 1635-1664. https://doi.org/10.1007/s11145-011-9336-5

Firda, Azkiyah \& Albiansyah (2021). Testing Breadth and Depth of Vocabulary Knowledge and ...

DOI: https://doi.org/10.33541/jet.v7i1.2434 
Qian, D. D. (1999). Assessing the roles of depth and breadth of vocabulary knowledge in reading comprehension. The Canadian Modern Language Review, 56, 282-308.

Qian, D. D. (2002). Investigating the relationship between vocabulary knowledge and academic reading performance: An assessment perspective. Language Learning, 52, 513-536.

Qian, D. D., \& Schedl, M. (2004). Evaluation of an in-depth vocabulary knowledge measure for assessing reading performance. Language Testing, 21(1), 28-52. https://doi.org/10.1191/02655322041t273oa

Read, J. (1993). The development of a new measure of L2 vocabulary knowledge. Language Testing, 10(3), 355-371. https://doi.org/10.1177/026553229301000308

Read, J. (2000). Assessing Vocabulary. In 免疫学杂志 (Issue 07). Cambridge University Press.

Read, J. (2007). Second Language Vocabulary Assessment: Current Practices and New Directions. International Journal of English Studies (IJES), 7(2), 105-126. https://doi.org/10.6018/ijes.7.2.49021

Roever, C., \& McNamara, T. (2006). Language testing: The social dimension. International Journal of Applied Linguistics, 16(2), 242-258. https://doi.org/10.1111/j.1473-4192.2006.00117.x

Rukmana, F. Z. (2016). Peningkatan Kemampuan Penguasaan Kosakata Melalui Metode Multisensori Pada Anak Tunarungu Kelas Ii Sekolah Dasar Luar Biasa Tunas Bhakti Pleret Bantul. Yogyakarta. Universitas Negeri Yogyakarta. Press.

Schmitt, N., Schmitt, D., \& Clapham, C. (2001). Developing and exploring the behaviour of two new versions of the Vocabulary Levels Test. Language Testing, 18(1), 5588. https://doi.org/10.1177/026553220101800103

Schmitt, N. (2000). Vocabulary in language teaching. New York: Cambridge University Press.

Şen, Y., \& Kuleli, M. (2015). The Effect of Vocabulary Size and Vocabulary Depth on Reading in EFL Context. Procedia - Social and Behavioral Sciences, 199, 555-562. https://doi.org/10.1016/j.sbspro.2015.07.546

Shen, Z. (2009). The Roles of Depth and Breadth of Vocabulary Knowledge in EFL Reading Performance. Asian Social Science, 4(12), 135-137. https://doi.org/10.5539/ass.v4n12p135

Wang, Z. (2014). A Correlation Analysis on the Depth and Breadth of ESL Learners' Vocabulary Knowledge and Their Overall Linguistic Competence. Theory and Practice in Language Studies, 4(12), 2460-2465. https://doi.org/10.4304/tpls.4.12.2460-2465 
Appendix: Students' Vocabulary Knowledge and Estimated Vocabulary Size

\begin{tabular}{|c|c|c|c|c|c|}
\hline No. & Respondent & Breadth & \begin{tabular}{|c|} 
Estimated \\
Vocabulary \\
Size
\end{tabular} & Depth & $\begin{array}{c}\text { Estimated } \\
\text { Vocabulary } \\
\text { Size }\end{array}$ \\
\hline 1 & AS & 18 & 1200 & 12 & 800 \\
\hline 2 & AM & 15 & 1000 & 12 & 800 \\
\hline 3 & APG & 12 & 800 & 15 & 1000 \\
\hline 4 & AH & 15 & 1000 & 24 & 1600 \\
\hline 5 & AR & 24 & 1600 & 24 & 1600 \\
\hline 6 & A & 15 & 1000 & 9 & 600 \\
\hline 7 & APP & 21 & 1400 & 18 & 1200 \\
\hline 8 & AY & 21 & 1400 & 12 & 800 \\
\hline 9 & ADA & 9 & 600 & 15 & 1000 \\
\hline 10 & BR & 24 & 1600 & 15 & 1000 \\
\hline 11 & DNP & 24 & 1600 & 9 & 600 \\
\hline 12 & DNP & 15 & 1000 & 6 & 400 \\
\hline 13 & DA & 21 & 1400 & 24 & 1600 \\
\hline 14 & DGA & 27 & 1800 & 15 & 1000 \\
\hline 15 & FAZI & 12 & 800 & 9 & 600 \\
\hline 16 & FAA & 18 & 1200 & 18 & 1200 \\
\hline 17 & IPY & 12 & 800 & 18 & 1200 \\
\hline 18 & IPP & 18 & 1200 & 21 & 1400 \\
\hline 19 & KRA & 21 & 1400 & 21 & 1400 \\
\hline 20 & LAF & 21 & 1400 & 18 & 1200 \\
\hline 21 & LKG & 12 & 800 & 15 & 1000 \\
\hline 22 & LL & 18 & 1200 & 12 & 800 \\
\hline 23 & LRS & 12 & 800 & 9 & 600 \\
\hline 24 & MT & 24 & 1600 & 18 & 1200 \\
\hline 25 & MA & 24 & 1600 & 9 & 600 \\
\hline 26 & MD & 3 & 200 & 6 & 400 \\
\hline 27 & MFR & 21 & 1400 & 24 & 1600 \\
\hline 28 & MR & 24 & 1600 & 12 & 800 \\
\hline 29 & PEB & 18 & 1200 & 21 & 1400 \\
\hline 30 & RNA & 18 & 1200 & 18 & 1200 \\
\hline 31 & RDPA & 18 & 1200 & 24 & 1600 \\
\hline 32 & RSI & 18 & 1200 & 18 & 1200 \\
\hline 33 & RSI & 21 & 1400 & 12 & 800 \\
\hline 34 & RA & 15 & 1000 & 3 & 200 \\
\hline 35 & $\mathbf{R J}$ & 9 & 600 & 12 & 800 \\
\hline 36 & RAS & 6 & 400 & 12 & 800 \\
\hline 37 & RBF & 18 & 1200 & 15 & 1000 \\
\hline 38 & RFS & 24 & 1600 & 21 & 1400 \\
\hline 39 & RA & 18 & 1200 & 12 & 800 \\
\hline 40 & RDJ & 3 & 200 & 24 & 1600 \\
\hline 41 & SF & 21 & 1400 & 24 & 1600 \\
\hline 42 & SAN & 21 & 1400 & 21 & 1400 \\
\hline 43 & SF & 24 & 1600 & 21 & 1400 \\
\hline 44 & SP & 24 & 1600 & 15 & 1000 \\
\hline 45 & SDL & 15 & 1000 & 24 & 1600 \\
\hline 46 & $\mathrm{~S}$ & 21 & 1400 & 18 & 1200 \\
\hline 47 & SK & 6 & 400 & 6 & 400 \\
\hline 48 & TPA & 6 & 400 & 6 & 400 \\
\hline 49 & TPR & 24 & 1600 & 21 & 1400 \\
\hline 50 & ZNM & 24 & 1600 & 21 & 1400 \\
\hline 51 & $Z S$ & 18 & 1200 & 15 & 1000 \\
\hline
\end{tabular}

Firda, Azkiyah \& Albiansyah (2021). Testing Breadth and Depth of Vocabulary Knowledge and ... 